\title{
ASSESSMENT OF FARMERS' KNOWLEDGE REGARDING CHILD LABOR IN AGRICULTURE: A CASE STUDY OF COTTON GROWERS IN DISTRICT BAHAWALPUR
}

\author{
M. Zeeshan*, U. Tariq, A. H. Makhdoom, A. Imran, L. A. Khan and Nawabudin \\ Sustainable Agriculture Program, World Wide Fund for Nature - Pakistan (WWF-Pakistan)
}

\begin{abstract}
The work which affects the education, dignity and health of a child is known as child labor. It exists in agriculture sector of Pakistan mostly in the form of hazardous work. The main objective of the study was to investigate the degree of knowledge of cotton growers on child labor issue with special reference to Decent Work of International Labor Organization (ILO). The study was conducted in Bahawalpur district where Decent Work has been implemented by World Wide Fund for Nature (WWF)-Pakistan since 2013 as a part of its Sustainable Agriculture Program. Three categories of farmers were identified among a total of 388 selected cotton growers i.e. Farmers having high level of awareness, farmers having basic level of awareness and farmers having no awareness of child labor. Farmers were also categorized into three groups on the basis of their land holding i.e. (Category 'a') 1-7 acres, (b) >7-20 acres and (c) >20-50 acres. The data was analyzed through descriptive statistical method. Among category ' $a$ ' $7.5 \%, 88.7 \%$ and $3.7 \%$ of the farmers had advance, basic and no awareness, respectively. Among category ' $b$ ' $7.2 \%$, $88.5 \%$ and $4.2 \%$ farmers had advance, basic and no awareness, respectively. Among category 'c' 5.8\%, 90.2\% and 3.9\% farmers had advance, basic and no awareness, respectively. Since there was a large proportion of those farmers who have only basic level of awareness on child labor among all the three land holding categories, therefore, there is a need to educate farmers on preventing child labor at their farms to promote sustainable cotton.
\end{abstract}

KEYWORDS: Child labor, cotton farming, hazardous work, education, pesticide hazards

*Corresponding author: (Email: zeeshanqureshi1986@gmail.com)

\section{INTRODUCTION}

According to International Labor Organization (ILO) "child labor is any activity other than play or study, paid or unpaid which is performed by child of the age of 15 or 14 in some countries" [1]. Rana [2] defines child labor as "The participation of school age children (515 years) in the labor force i.e. work for wage or in house hold enterprises to earn a living for themselves or to support household income. "Child labor, is, generally speaking, work that harms them or exploits them in some way (physically, mentally, morally or by blocking access to education and normal health growth)" [3].

ILO reported under the International Program on Elimination of Child labor that about 300 million children between the age 5-17 are engaged in some kind of child labor worldwide i.e. more than 200 million are laborers and 125 million are involved in hazardous work [4]. One of the most dangerous sections involving child labor and under regulated economic sector worldwide for all workers is in agriculture; about 
$70 \%$ of child labor happened in agriculture sector i.e. children of 5-14 years. Child labour in agriculture sector creates many problems; some of them are mentioned below [5]:

i. Muscle injuries due to carrying heavy loads

ii. Poisoning, allergy and other health problems due to exposure to pesticides and pesticides application as well.

iii. Injuries from handling heavy machinery

Globally Pakistan stands at $3^{\text {rd }}$ position in the world about occurrence of child labor [6]. According to report of International Programme on the Elimination of Child labor, scenario about child labor in agriculture sector of Pakistan showed that about $90 \%$ children working in crops performing different tasks, and about $84 \%$ of children are directly or indirectly involved in cotton sector although these children were dropped out or not attended school that fall directly under school [7]. The main objective of the study was to assess the knowledge of cotton growers because prevalence of child labor is highest in cotton farming amongst all agricultural crops. The present study provided deep insight of current scenario of child labor in main cotton growing belt of Pakistan (District Bahawalpur).

\section{METHODOLOGY}

The research was conducted with the registered farmers of WWF-Pakistan in the year 2014 at district Bahawalpur, Pakistan. The farmers were categories in three groups according to their land holding i.e. category ' $a$ ' (1-7 acres), category 'b' (7-20 acres) and category ' $c$ ' (20-50) acres. A total of 388 farmers were assessed about their knowledge regarding child labor. For this purpose a survey, using 10 different pictorial tools elaborating different forms of child labor in cotton farming was conducted which are

- $\quad$ Spraying Pesticides

- Carrying Cotton Loads

- Children working with dangerous tools

- Children tackling animals for agriculture utility

- Hard field work

- Seed Treatment

- General good practice

- Importance of Education for children

- Weeding

- Children working Around Machines

The farmers of three categories were asked whether they have knowledge about the child labor or not, and then evaluate the level of awareness which was categorize as

1. Advance level:

Farmers having good knowledge and adopting procedure

2. Basic level:

Farmers having knowledge about the practices

3. Low level:

Farmers having no or low level of awareness

A scale is given in table 1 to categorize the level of the farmers based on the pictorial form.

\subsection{Statistical Analysis}

The data was analyzed through descriptive method to find out the percentages. 
Table 1: Evaluation Scale.

Evaluation Scale

\begin{tabular}{|c|c|c|c|c|}
\hline Sr. No. & Pictogram & Advance & Basic & Low \\
\hline 1 & Spraying Pesticide & $\begin{array}{l}\text { Spraying } \\
\text { pesticide is } \\
\text { hazardous }\end{array}$ & $\begin{array}{l}\text { Giving wrong } \\
\text { reasons. }\end{array}$ & Work is acceptable \\
\hline 2 & Carrying cotton load & $\begin{array}{l}\text { Carrying load is } \\
\text { hazardous. }\end{array}$ & $\begin{array}{l}\text { According to } \\
\text { farmer work is } \\
\text { hazardous but } \\
\text { reason provided is } \\
\text { wrong child is } \\
\text { working too hard. }\end{array}$ & $\begin{array}{l}\text { Farmer does not identify it as } \\
\text { hazardous task }\end{array}$ \\
\hline 3 & $\begin{array}{l}\text { Children working with } \\
\text { dangerous tools }\end{array}$ & $\begin{array}{l}\text { Farmer identify } \\
\text { that working with } \\
\text { sharp tools as } \\
\text { hazardous. }\end{array}$ & $\begin{array}{l}\text { Farmer give reason } \\
\text { that the sharp tools } \\
\text { may not be } \\
\text { hazardous and } \\
\text { that they may be } \\
\text { under some } \\
\text { conditions. }\end{array}$ & $\begin{array}{l}\text { Farmer does not think that it is } \\
\text { hazardous. }\end{array}$ \\
\hline 4 & $\begin{array}{l}\text { Children tackling } \\
\text { animals for agriculture } \\
\text { utility }\end{array}$ & $\begin{array}{l}\text { Farmer Answer } \\
\text { that it is } \\
\text { dangerous for } \\
\text { children. }\end{array}$ & $\begin{array}{l}\text { Farmer give the } \\
\text { reason that the } \\
\text { child is handling } \\
\text { animal in wrong } \\
\text { way. }\end{array}$ & $\begin{array}{l}\text { Farmer does not think that it is } \\
\text { hazardous. }\end{array}$ \\
\hline 5 & Hard Field work & $\begin{array}{l}\text { Farmer } \\
\text { emphasizing the } \\
\text { need to limit } \\
\text { intensity of work } \\
\text { for children. }\end{array}$ & $\begin{array}{l}\text { Farmer give wrong } \\
\text { reason for this. }\end{array}$ & $\begin{array}{l}\text { Farmer does not think that it is } \\
\text { hazardous. }\end{array}$ \\
\hline 6 & Seed Treatment & $\begin{array}{l}\text { Farmer identify it } \\
\text { as hazardous task } \\
\text { because it is of } \\
\text { inappropriate to } \\
\text { handle by } \\
\text { children. }\end{array}$ & $\begin{array}{l}\text { Farmer identify this } \\
\text { as hazardous task } \\
\text { but does not } \\
\text { reason properly as } \\
\text { the child is } \\
\text { handling } \\
\text { pesticides. }\end{array}$ & $\begin{array}{l}\text { Farmer does not think that it is } \\
\text { hazardous. }\end{array}$ \\
\hline 7 & $\begin{array}{l}\text { General Good } \\
\text { Practices }\end{array}$ & $\begin{array}{l}\text { Farmer does not } \\
\text { identify any task } \\
\text { as hazardous and } \\
\text { identifies the }\end{array}$ & $\begin{array}{l}\text { Identifies the } \\
\text { importance of } \\
\text { supervision. }\end{array}$ & $\begin{array}{l}\text { Farmer incorrectly identify the } \\
\text { working of children as } \\
\text { hazardous. }\end{array}$ \\
\hline
\end{tabular}




\begin{tabular}{|c|c|c|c|c|}
\hline & & $\begin{array}{l}\text { importance of } \\
\text { the supervision. }\end{array}$ & & \\
\hline 8 & $\begin{array}{l}\text { Importance of } \\
\text { Education for children }\end{array}$ & $\begin{array}{l}\text { Farmer identifies it } \\
\text { as good practice } \\
\text { that children are } \\
\text { not working } \\
\text { during school } \\
\text { hours. }\end{array}$ & $\begin{array}{l}\text { Farm just identify it } \\
\text { as the good } \\
\text { practice. }\end{array}$ & $\begin{array}{l}\text { Farmer disagrees and take is } \\
\text { as the wrong to attend the } \\
\text { school whither there is work } \\
\text { on farm. }\end{array}$ \\
\hline 9 & Weeding & $\begin{array}{l}\text { Bending during } \\
\text { work could } \\
\text { damage his } \\
\text { back. }\end{array}$ & $\begin{array}{l}\text { work is too hard for } \\
\text { the child }\end{array}$ & Task is not hazardous. \\
\hline 10 & $\begin{array}{l}\text { Children working } \\
\text { Around Machines }\end{array}$ & $\begin{array}{l}\text { Working with and } \\
\text { around the } \\
\text { machines is } \\
\text { hazardous for } \\
\text { children. }\end{array}$ & $\begin{array}{l}\text { According to } \\
\text { farmers work is } \\
\text { hazardous but } \\
\text { giving wrong } \\
\text { reason }\end{array}$ & $\begin{array}{l}\text { Farmer does not think that } \\
\text { machines are hazardous for } \\
\text { children. }\end{array}$ \\
\hline
\end{tabular}

\section{RESULTS AND DISCUSSIONS}

The present research revealed the following results:

Table 2: Farmers' knowledge regarding Child Labor for "Spraying Pesticide".

\begin{tabular}{|c|c|c|c|c|}
\hline \multicolumn{5}{|c|}{ Spraying Pesticides } \\
\hline $\begin{array}{l}\text { Sr. } \\
\text { No. }\end{array}$ & $\begin{array}{l}\text { Land } \\
\text { holding } \\
\text { (acres) }\end{array}$ & $\begin{array}{l}\text { Advance } \\
\text { level of } \\
\text { awareness } \\
\text { (\%age) }\end{array}$ & $\begin{array}{l}\text { Basic Level } \\
\text { of } \\
\text { Awareness } \\
\text { (\%age) }\end{array}$ & $\begin{array}{l}\text { Low Level of } \\
\text { Awareness } \\
\text { (\%age) }\end{array}$ \\
\hline 1 & $\begin{array}{l}\text { 'Category } \\
\text { a' (1-7) }\end{array}$ & 18.2 & 77.9 & 3.8 \\
\hline 2 & $\begin{array}{l}\text { 'Category } \\
\text { b' (7-20) }\end{array}$ & 15.0 & 81.9 & 3.0 \\
\hline 3 & $\begin{array}{l}\text { 'Category } \\
c^{\prime}(20-50)\end{array}$ & 24.3 & 72.9 & 2.7 \\
\hline
\end{tabular}

Table 2 shows the data collected for the knowledge of farmer regarding the children dealing with spraying pesticides. The results reveal that $18.2 \%, 77.9 \%$ and $3.8 \%$ of total famers of 'category a' having advance, basic and low level of knowledge respectively. Whereas 15.0\%, $81.9 \%$ and $3.0 \%$ of total famers of 'category b' having advance, basic and low level of knowledge respectively while $18.0 \%, 54.0 \%$ and $2.7 \%$ of total famers of 'category c' having advance, basic and low level of knowledge respectively.

Table 3: Farmers' knowledge regarding Child labor for "Carrying Cotton Loads".

\begin{tabular}{|c|c|c|c|c|}
\hline \multicolumn{5}{|c|}{ Carrying Cotton Loads } \\
\hline $\begin{array}{l}\text { Sr. } \\
\text { No. }\end{array}$ & $\begin{array}{l}\text { Land } \\
\text { holding } \\
\text { (acres) }\end{array}$ & $\begin{array}{l}\text { Advance } \\
\text { level of } \\
\text { awareness } \\
\text { (\%age) }\end{array}$ & $\begin{array}{l}\text { Basic Level of } \\
\text { Awareness } \\
\text { (\%age) }\end{array}$ & $\begin{array}{l}\text { Low Level } \\
\text { of } \\
\text { Awareness } \\
\text { (\%age) }\end{array}$ \\
\hline 1 & $\begin{array}{l}\text { 'Category } \\
a^{\prime}(1-7)\end{array}$ & 4.9 & 91.7 & 3.3 \\
\hline 2 & $\begin{array}{l}\text { 'Category } \\
\text { b' (7-20) }\end{array}$ & 6.0 & 91.7 & 2.2 \\
\hline 3 & $\begin{array}{l}\text { 'Category } \\
c^{\prime}(20-50)\end{array}$ & 5.4 & 89.1 & 5.4 \\
\hline
\end{tabular}


Table 3 shows the data collected for the knowledge of farmer regarding the children in carrying cotton loads. The results indicate that $4.9 \%, 91.7 \%$ and $3.3 \%$ of total famers of 'category a' having advance, basic and low level of knowledge respectively. Whereas $6.0 \%$, $91.7 \%$ and $2.2 \%$ of total famers of 'category b' having advance, basic and low level of knowledge respectively while $5.4 \%, 89.1 \%$ and $5.4 \%$ of total famers of 'category $c$ ' having advance, basic and low level of knowledge respectively.

Table 4: Farmers' knowledge regarding "children working with dangerous tools".

\begin{tabular}{lllll}
\hline \multicolumn{5}{c}{ Dangerous tools } \\
\hline Sr. & Land & Advance & Basic Level & Low \\
No. & holding & level of & of & Level of \\
& (acres) & $\begin{array}{l}\text { awareness } \\
\text { (\%age) }\end{array}$ & $\begin{array}{l}\text { Awareness } \\
\text { (\%age) }\end{array}$ & Awaren \\
& & & & ess \\
(\%age)
\end{tabular}

Table 4 shows the data collected for the knowledge of farmer regarding the children working with dangerous tools. The results indicate that $4.9 \%, 89.5 \%$ and $5.5 \%$ of total famers of 'category a' having advance, basic and low level of knowledge of respectively. Whereas $7.5 \%, 87.9 \%$ and $4.5 \%$ of total famers of 'category b' having advance, basic and low level of knowledge respectively, while $1.3 \%$, $97.2 \%$ and $1.3 \%$ of total famers of 'category c' having advance, basic and low level of knowledge respectively.
Table 5: Farmers' knowledge regarding "Children tackling animals for agriculture utility".

\begin{tabular}{|c|c|c|c|c|}
\hline \multicolumn{5}{|c|}{ Tackling animals for agriculture utility } \\
\hline $\begin{array}{l}\text { Sr. } \\
\text { No. }\end{array}$ & $\begin{array}{l}\text { Land } \\
\text { holding } \\
\text { (acres) }\end{array}$ & $\begin{array}{l}\text { Advance } \\
\text { level of } \\
\text { awareness } \\
\text { (\%age) }\end{array}$ & $\begin{array}{l}\text { Basic Level } \\
\text { of } \\
\text { Awareness } \\
\text { (\%age) }\end{array}$ & $\begin{array}{l}\text { Low Level } \\
\text { of } \\
\text { Awarene } \\
\text { ss } \\
\text { (\%age) }\end{array}$ \\
\hline 1 & $\begin{array}{l}\text { 'Category } \\
\text { a' (1-7) }\end{array}$ & 3.3 & 91.7 & 4.9 \\
\hline 2 & $\begin{array}{l}\text { 'Category } \\
\text { b'(7-20) }\end{array}$ & 5.2 & 90.2 & 4.5 \\
\hline 3 & $\begin{array}{l}\text { 'Category } \\
c^{\prime}(20-50)\end{array}$ & 2.7 & 95.9 & 1.3 \\
\hline
\end{tabular}

Table 5 shows the data collected for the knowledge of farmer regarding children tackling animals for agriculture utility. The results indicate that $3.3 \%, 91.7 \%$ and $4.9 \%$ of total famers of 'category a' having advance, basic and low level of knowledge of respectively. Whereas $5.2 \%, 90.2 \%$ and $4.5 \%$ of total famers of 'category b' having advance, basic and low level of knowledge respectively, while $2.7 \%$, $95.9 \%$ and $1.3 \%$ of total famers of 'category c' having advance, basic and low level of knowledge respectively.

Table 6: Farmers' knowledge regarding Child labor for working with "Hard field work".

\begin{tabular}{|c|c|c|c|c|}
\hline \multicolumn{5}{|c|}{ Hard field work } \\
\hline $\begin{array}{l}\text { Sr. } \\
\text { No. }\end{array}$ & $\begin{array}{l}\text { Land } \\
\text { holding } \\
\text { (acres) }\end{array}$ & $\begin{array}{l}\text { Advance } \\
\text { level of } \\
\text { awareness } \\
\text { (\%age) }\end{array}$ & $\begin{array}{l}\text { Basic Level } \\
\text { of } \\
\text { Awareness } \\
\text { (\%age) }\end{array}$ & $\begin{array}{l}\text { Low } \\
\text { Level of } \\
\text { Awarene } \\
\text { ss } \\
\text { (\%age) }\end{array}$ \\
\hline 1 & $\begin{array}{l}\text { 'Category } \\
\text { a' (1-7) }\end{array}$ & 3.3 & 95.5 & 1.1 \\
\hline 2 & $\begin{array}{l}\text { 'Category } \\
\text { b'(7-20) }\end{array}$ & 4.5 & 91.7 & 3.7 \\
\hline
\end{tabular}




\begin{tabular}{lllll}
\hline 3 & 'Category & 1.3 & 97.2 & 1.3 \\
& $C^{\prime}(20-50)$ & & & \\
\hline
\end{tabular}

Table 6 shows the data collected for the knowledge of farmer regarding the children dealing with hard field work. The results reveal that $3.3 \%, 95.5 \%$ and $1.1 \%$ of total famers of 'category a' having advance, basic and low level of knowledge respectively. Whereas $4.5 \%$, $91.7 \%$ and $3.7 \%$ of total famers of 'category b' having advance, basic and low level of knowledge respectively, while $1.3 \%, 97.2 \%$ and $1.3 \%$ of total famers of 'category $c$ ' having advance, basic and low level of knowledge respectively.

Table 7: Farmers' knowledge regarding Child labor in "Seed Treatment".

\begin{tabular}{|c|c|c|c|c|}
\hline \multicolumn{5}{|c|}{ Seed Treatment } \\
\hline $\begin{array}{l}\text { Sr. } \\
\text { No. }\end{array}$ & $\begin{array}{l}\text { Land } \\
\text { holding } \\
\text { (acres) }\end{array}$ & $\begin{array}{l}\text { Advance } \\
\text { level of } \\
\text { awareness } \\
\text { (\%age) }\end{array}$ & $\begin{array}{l}\text { Basic Level } \\
\text { of } \\
\text { Awareness } \\
\text { (\%age) }\end{array}$ & $\begin{array}{l}\text { Low Level } \\
\text { of } \\
\text { Awareness } \\
\text { (\%age) }\end{array}$ \\
\hline 1 & $\begin{array}{l}\text { 'Category } \\
\text { a' (1-7) }\end{array}$ & 8.8 & 85.6 & 5.5 \\
\hline 2 & $\begin{array}{l}\text { 'Category } \\
\text { b' (7-20) }\end{array}$ & 6.0 & 83.4 & 10.5 \\
\hline 3 & $\begin{array}{l}\text { 'Category } \\
\text { c' (20-50) }\end{array}$ & 5.4 & 83.7 & 10.8 \\
\hline
\end{tabular}

The table 7 shows the data collected for the knowledge of farmer regarding the children doing seed treatment. The results reveal that $8.8 \%, 85.6 \%$ and $5.5 \%$ of total famers of 'category a' having advance, basic and low level of knowledge respectively. Whereas $6.0 \%$, $83.4 \%$ and $10.5 \%$ of total famers of 'category b' having advance, basic and low level of knowledge respectively, while $5.4 \%, 83.7 \%$ and $10.8 \%$ of total famers of 'category c' having advance, basic and low level of knowledge respectively.

Table 8: Farmers' knowledge regarding Child labor in "General good practice".

\begin{tabular}{lllll}
\hline \multicolumn{5}{c}{ General good practice } \\
\hline Sr. & Land & Advance level & Basic & Low Level \\
No. & holding & of awareness & Level of & of \\
& (acres) & (\%age) & $\begin{array}{l}\text { Awareness } \\
\text { (\%age) }\end{array}$ & $\begin{array}{l}\text { Awareness } \\
\text { (\%age) }\end{array}$ \\
1 & 'Category & 10.4 & 85.0 & 4.4 \\
2 & $\begin{array}{l}\text { 'C' (1-7) } \\
\text { 'Category }\end{array}$ & 6.0 & & \\
3 & $\begin{array}{l}\text { b' (7-20) } \\
\text { 'Category }\end{array}$ & 2.7 & 89.4 & 4.5 \\
c' (20-50) & & 89.1 & 8.1 \\
\hline
\end{tabular}

Table 8 shows the data collected for the knowledge of farmer regarding the child labor in General good practice. The results reveal that $10.49 \%, 85.08 \%$ and $4.41 \%$ of total famers of 'category a' having advance, basic and low level of knowledge respectively. Whereas $6.01 \%$, $89.47 \%$ and $4.51 \%$ of total famers of 'category b' having advance, basic and low level of knowledge respectively, while $2.7 \%, 89.18 \%$ and $8.10 \%$ of total famers of 'category $c$ ' having advance, basic and low level of knowledge respectively.

Table 9: Farmers' knowledge regarding importance of "Education" for children.

\begin{tabular}{lllll}
\hline \multicolumn{5}{c}{ Importance of "Education" for children } \\
\hline Sr. & Land & Advance & Basic Level & Low Level \\
No. & holding & level of & of & of \\
& (acres) & awareness & Awareness & Awareness \\
& & (\%age) & (\%age) & (\%age) \\
1 & 'Category & 8.2 & 91.7 & 0.0 \\
& $\begin{array}{l}\text { a' (1-7) } \\
2\end{array}$ & & & \\
& 'Category & 8.2 & 91.7 & 0.0 \\
\hline
\end{tabular}




\begin{tabular}{lllll}
\hline 3 & 'Category & 4.0 & 95.9 & 0.0 \\
& $c$ '(20-50) & & & \\
\hline
\end{tabular}

The table 9 shows the data collected for the knowledge of farmer regarding importance of education of children. The results reveal that $8.2 \%, 91.7 \%$ and $0.0 \%$ of total famers of 'category a' having advance, basic and low level of knowledge respectively. Whereas $8.2 \%$, $91.7 \%$ and $0.0 \%$ of total famers of 'category b' having advance, basic and low level of knowledge respectively, while $4.0 \%, 95.9 \%$ and $0.0 \%$ of total famers of 'category c' having advance, basic and low level of knowledge respectively.

Table 10: Farmers' knowledge regarding child labor in "Weeding".

Table 11: Farmers' knowledge regarding "Children working Around Machines".

\begin{tabular}{|c|c|c|c|c|}
\hline \multicolumn{5}{|c|}{ Children working Around Machines } \\
\hline $\begin{array}{l}\text { Sr. } \\
\text { No. }\end{array}$ & $\begin{array}{l}\text { Land } \\
\text { holding } \\
\text { (acres) }\end{array}$ & $\begin{array}{l}\text { Advance } \\
\text { level of } \\
\text { awareness } \\
\text { (\%age) }\end{array}$ & $\begin{array}{l}\text { Basic Level } \\
\text { of } \\
\text { Awareness } \\
\text { (\%age) }\end{array}$ & $\begin{array}{l}\text { Low Level } \\
\text { of } \\
\text { Awareness } \\
\text { (\%age) }\end{array}$ \\
\hline 1 & $\begin{array}{l}\text { 'Category } \\
\text { a' (1-7) }\end{array}$ & 8.2 & 86.1 & 5.5 \\
\hline 2 & $\begin{array}{l}\text { 'Category } \\
\text { b'(7-20) }\end{array}$ & 7.5 & 88.7 & 3.7 \\
\hline 3 & $\begin{array}{l}\text { 'Category } \\
c^{\prime}(20-50)\end{array}$ & 5.4 & 87.8 & 6.7 \\
\hline
\end{tabular}

Table 11 shows the data collected for the knowledge of farmer regarding children working around machines. The results reveal

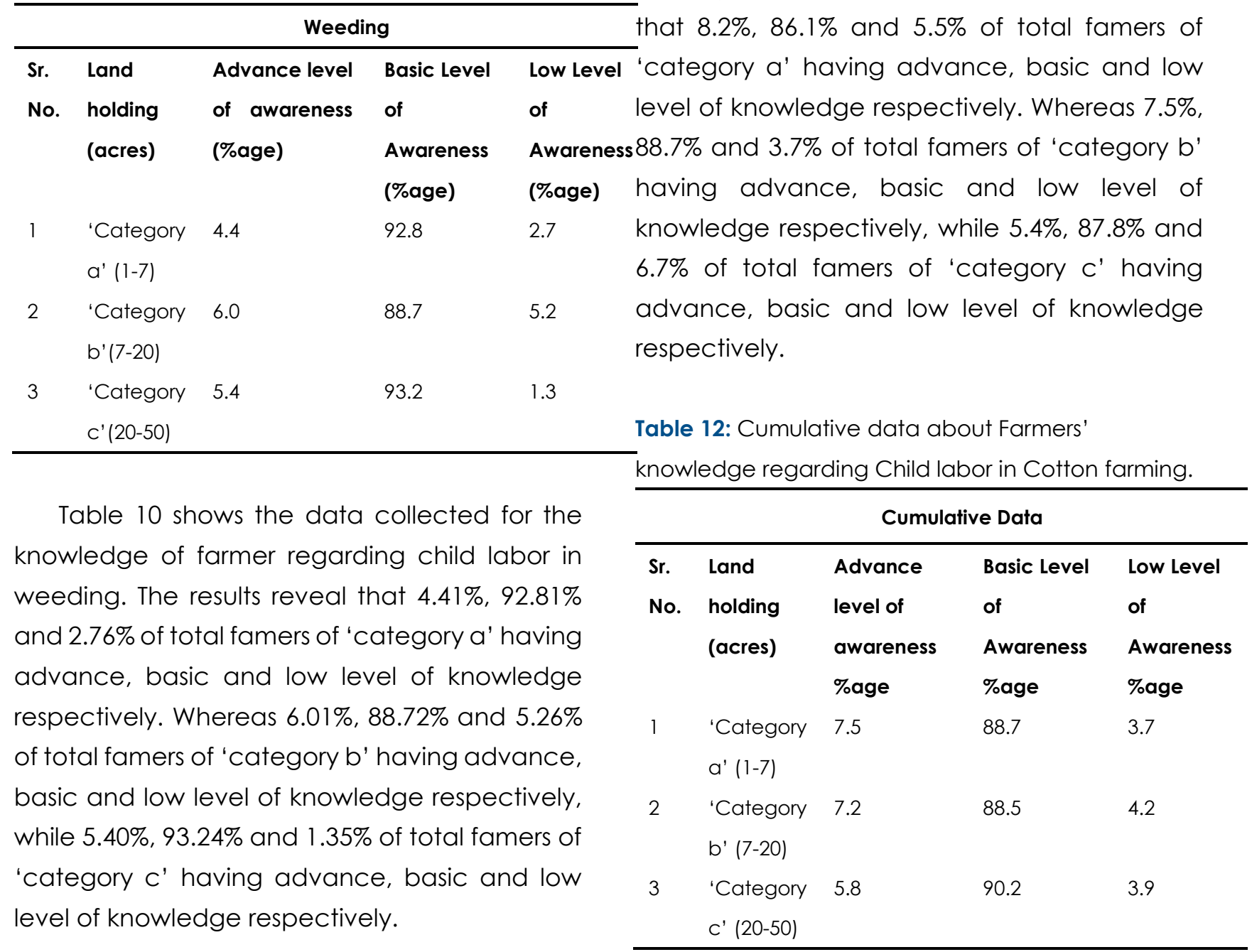


Table 12 shows the cumulative data farmer's knowledge regarding child labor in cotton farming. The data reveal that among the category ' $a$ ' $7.5 \%, 88.7 \%$ and $3.7 \%$ of the farmers had advance, basic and low level of awareness, respectively. Among category ' $b$ ' $7.2 \%, 88.5 \%$ and $4.2 \%$ farmers had advance, basic and low level of awareness, respectively. Among category 'c' 5.8\%, 90.2\% and $3.9 \%$ farmers had advance, basic and low level of awareness, respectively. Since the large proportion of farmers having only the basic level of awareness on child labor. The research reveals that very small proportion of farmers are having advance and low level of knowledge. But the farmers with advance level of knowledge are those farmers small in number or percentages who are adopting good practices about child labor elimination or eradication. Whereas, for the farmers with low level of knowledge of good practices in this regard question arises about adopting good practices. The possible reason behind the current scenario could be lack of interest in education and poverty as reported by Ameen et al. [8].

\section{CONCLUSION}

There is a deep concern to educate farmers efficiently; the main focus must be on those farmers who fall under the category of low level of knowledge. The task could be done through spreading decent work of ILO working in country like Pakistan where there is immense occurrence of child labor in agriculture sector.

\section{References}

[1] A. K. Malik, N. A. Bhutto, D. Shaikh, E. Akhter, F. Butt, Another Real Fact about Child Labor: A Comparative Study between Districts of Two Provinces of Pakistan. Proceedings of 2 nd International Conference on Business Management.

[2] E. Rana, Gender Analysis of Children's Activities in Pakistan, Pak. Dev. Rev. 47 (2008) 169-195.

[3] A. K Kiani, A Significant Impact of Child Labor on Pakistan's Economy. $8^{\text {th }}$ International Conference on Making Innovation Work for Society: Linking, Leveraging and Learning, November 1-3, (2010).

[4] Hagemann, F. Y. Diallo, A. Etienne, F. Mehran, IPEC: Global Child Labour Trends 2000 to 2004. ILO, Statistical Information and Monitoring Programme on Child Labour (SIMPOC), Geneva, (2006).

[5] ILO, "ILO Statement on Child Labor in Agriculture at the 494th Meeting of the Standing Committee of the International Cotton Advisory Committee", Washington DC, (2008).

[6] A. Hussain, Slaves to Inaction. The News International. Print. 2 February 2014.

[7] The effect of work on children's health: report of research on ten occupational sectors in Pakistan / international Labor Office, International Programme on the Elimination of Child Labor (IPEC).Geneva: ILO, 2013.

[8] Ameen, F. A. Sajjad, A. H. Makhdum, A. Imran, M. Asif, S. Akbar, Decent Work Trends and Work Life Quality among Rural Communities of District Jhang, Pakistan, Acad. Res. Int. 6 (2015) 214-221. 